\title{
First post-Cambrian records of the reticulosan sponges Valospongia and Hintzespongia from the late Tremadocian of North Wales
}

\author{
Joseph P. Botting and Lucy A. Muir \\ Acta Palaeontologica Polonica 59 (1), 2014: 241-252 doi: http://dx.doi.org/10.4202/app.2012.0016
}

A new sponge fauna has been discovered in silty mudstone of the early Migneintian (late Tremadocian, Ordovician) of North Wales. The assemblage is dominated by reticulosan hexactinellids, including several species bearing parietal gaps; this feature is common among Cambrian hexactinellids, but is rare in Ordovician faunas. Of particular significance is Valospongia bufo sp. nov., representing the first record of the genus outside the Middle Cambrian of Utah, USA. A single specimen assigned to Hintzespongia? sp. is also described, and also represents the first occurrence outside the Laurentian Burgess Shale-type faunas. This fauna indicates that deeper-water hexactinellids from the Burgess Shale-type faunas survived in places into at least the Early Ordovician, in addition to the Cambrian-type protomonaxonid assemblage seen in the Fezouata Biota.

Key words: Reticulosa, Porifera, Silicea, exceptional preservation, Gwynedd, Migneintian, Tremadoc, Cambrian, North Wales, UK.

Joseph P. Botting [acutipuerilis@yahoo.co.uk] and Lucy A. Muir [lucy@asoldasthehills.org], State Key Laboratory of Palaeobiology and Stratigraphy, Nanjing Institute of Geology and Palaeontology, Chinese Academy of Sciences, 39 East Beijing Road, Nanjing 210008, China.

This is an open-access article distributed under the terms of the Creative Commons Attribution License (for details please see creativecommons.org), which permits unrestricted use, distribution, and reproduction in any medium, provided the original author and source are credited. 
